\title{
Hydrometallurgical Approach for Leaching of Metals from Copper Rich Side Stream Originating from Base Metal Production
}

\author{
Udit Surya Mohanty ${ }^{1}$, Lotta Rintala $^{2}$, Petteri Halli $^{1}{ }^{\text {(D) }}$, Pekka Taskinen ${ }^{1}{ }^{(1)}$ and \\ Mari Lundström ${ }^{1, *}$ \\ 1 Department of Chemical and Metallurgical Engineering, School of Chemical Engineering, Aalto University, \\ Vuorimiehentie 2, P.O. Box 16200, FI-00076 AALTO, Espoo (Otaniemi) 02150, Finland; \\ udit.mohanty@aalto.fi (U.S.M.); petteri.halli@aalto.fi (P.H.); pekka.taskinen@aalto.fi (P.T.) \\ 2 VTT Technical Research Centre of Finland Ltd., Solutions for Natural Resources and Environment, \\ Biologinkuja 7, ESPOO, P.O. Box 1000, FI-02044 VTT, Finland; lotta.rintala@vtt.fi \\ * Correspondence: mari.lundstrom@aalto.fi; Tel.: +358-9-47001
}

Received: 17 November 2017; Accepted: 5 January 2018; Published: 8 January 2018

\begin{abstract}
Pyrometallurgical metal production results in side streams, such as dusts and slags, which are carriers of metals, though commonly containing lower metal concentrations compared to the main process stream. In order to improve the circular economy of metals, selective leaching of copper from an intermediate raw material originating from primary base metal production plant was investigated. The raw material investigated was rich in $\mathrm{Cu}(12.5 \%), \mathrm{Ni}(2.6 \%), \mathrm{Zn}(1.6 \%)$, and $\mathrm{Fe}(23.6 \%)$ with the particle size $\mathrm{D}_{80}$ of $124 \mu \mathrm{m}$. The main compounds present were nickel ferrite $\left(\mathrm{NiFe}_{2} \mathrm{O}_{4}\right)$, fayalite $\left(\mathrm{Fe}_{2} \mathrm{SiO}_{4}\right)$, cuprite $\left(\mathrm{Cu}_{2} \mathrm{O}\right)$, and metallic copper. Leaching was studied in 16 different solutions. The results revealed that copper phases could be dissolved with high yield $(>90 \%)$ and selectivity towards nickel $(\mathrm{Cu} / \mathrm{Ni}>7)$ already at room temperature with the following solutions: $0.5 \mathrm{M} \mathrm{HCl}$, $1.5 \mathrm{M} \mathrm{HCl}, 4 \mathrm{M} \mathrm{NaOH}$, and $2 \mathrm{M} \mathrm{HNO}_{3}$. A concentration of $4 \mathrm{M} \mathrm{NaOH}$ provided a superior selectivity between $\mathrm{Cu} / \mathrm{Ni}(340)$ and $\mathrm{Cu} / \mathrm{Zn}(51)$. In addition, $1-2 \mathrm{M} \mathrm{HNO}_{3}$ and $0.5 \mathrm{M} \mathrm{HCl}$ solutions were shown to result in high $\mathrm{Pb}$ dissolution (>98\%). Consequently, $0.5 \mathrm{M} \mathrm{HCl}$ leaching is suggested to provide a low temperature, low chemical consumption method for selective copper removal from the investigated side stream, resulting in PLS (pregnant leach solution) which is a rich in $\mathrm{Cu}$ and lead free residue, also rich in $\mathrm{Ni}$ and $\mathrm{Fe}$.
\end{abstract}

Keywords: base metal production; intermediate; nickel iron oxide; fayalite; cuprite; leaching

\section{Introduction}

The growth in metal production has resulted in a gradual decrease in metal grades of ore deposits. Therefore, new technologies and flow-sheets are needed for the more efficient utilization of ore processing tailings, metallurgical slags, flue dusts, etc. In the base metal production, various solid side-streams are generated, such as slags, dusts, and leach residues. Inherently, these side-streams contain valuable base metals.

Thermodynamics determines the distributions of metals between metal and slag in high temperature processing [1-3]. In addition, kinetics and physical entrainment cause metal traces ending up to the slag in different steps of the production. About $60 \%$ of the world's copper and $50 \%$ of world sulphidic nickel production comes from plants using flash smelting furnace (FSF) technologies [4]. The main advantages of the FSF processes are high sulfur recovery, flexibility to feed materials and the efficient energy utilization [5]. The subsequent converting takes place in two sequential steps: 
(a) The FeS elimination or slag making stage

$$
2 \mathrm{FeS}_{(\mathrm{s})}+3 \mathrm{O}_{2(\mathrm{~g})}+2 \mathrm{SiO}_{2(\mathrm{~s})}=2 \mathrm{FeO} \cdot \mathrm{SiO}_{2(\mathrm{~s})}+2 \mathrm{SO}_{2(\mathrm{~g})}
$$

(b) The copper making stage

$$
\mathrm{Cu}_{2} \mathrm{~S}_{(\mathrm{s})}+2 \mathrm{O}_{2(\mathrm{~g})}=2 \mathrm{Cu}(\mathrm{s})+2 \mathrm{SO}_{2(\mathrm{~g})}
$$

As the process throughputs are generally high [6-8] the slags of the primary production can present a valuable secondary raw materials for metal recovery in future.

The composition of slags in base metal processing vary depending on the process and raw material. Copper flash smelting furnace slag generally consist of $30-50 \% \mathrm{Fe}, 30-40 \% \mathrm{SiO}_{2}, 1-10 \% \mathrm{Al}_{2} \mathrm{O}_{3}, 1-16 \%$ $\mathrm{CaO}$ and $0.2-1.2 \%$ of $\mathrm{Cu}$ [9]. Copper is mainly entrapped in the slag as chalcocite and metallic copper, as well as trace copper oxide [10]. The converter slag is usually characterized by $20-25 \% \mathrm{SiO}_{2}, 40-45 \%$ $\mathrm{Fe}$, and $5 \% \mathrm{Cu}$. The slags of anode furnace differs from the converter slags due its very high copper content, containing typically above 50 wt. \% $\mathrm{CuO}_{x}, 30-35$ wt. \% FeO, 5-15 wt. \% SiO 2 , and minor amounts of $\mathrm{As}, \mathrm{Sb}$, and $\mathrm{Pb}[11,12]$. Nickel flash smelting furnace slag has been reported to contain $8.7 \% \mathrm{Fe}_{2} \mathrm{SiO}_{4}, 10 \% \mathrm{Fe}_{3} \mathrm{O}_{4}, 20.5 \% \mathrm{SiO}_{2}, 3.1 \% \mathrm{Al}_{2} \mathrm{O}_{3}, 1.3 \% \mathrm{MgO}$, and $1.1 \% \mathrm{CaO}$ [13]. Generally, the slag former used is $\mathrm{SiO}_{2}$.

Industrial smelting and converting slags are cleaned before discarding them. In most cases an electric furnace settling or reduction is used, but some copper smelters use milling and slag flotation.

In the literature, new methods for slag cleaning have been studied for eliminating trace element or cutting their internal circulations in the smelter. Thus, the impurity levels in the slags and anode copper will be lowered. Roasting of the converter slag with ferric sulphate and selective sulphation roasting are the documented pyrometallurgical methods used for the recovery of nickel, copper and zinc $[14,15]$. Also, pyro-hydrometallurgical methods involving acid roasting or thermal decomposition followed by water leaching have been suggested [16-18]. Various hydrometallurgical methods have been developed using lixiviants such as acids, bases, and salts for base metal extraction. Atmospheric leaching of different slag fractions has been studied in $\mathrm{H}_{2} \mathrm{SO}_{4}, \mathrm{FeSO}_{4},\left(\mathrm{NH}_{4}\right)_{2} \mathrm{SO}_{4}, \mathrm{FeS}_{2}, \mathrm{NaCl}$, and $\mathrm{FeCl}_{2}$ media [19-23]. In addition, pressure leaching of copper slag containing $4.03 \% \mathrm{Cu}, 0.48 \% \mathrm{Co}$, and $1.98 \% \mathrm{Ni}$ at $130{ }^{\circ} \mathrm{C}$ have resulted in significant recoveries of $\mathrm{Cu}, \mathrm{Co}$, and $\mathrm{Ni}$, amounting to 90\% [24]. Leaching with aqueous sulfur dioxide has also proven effective in recovering $77 \%$ Co and $35 \%$ Ni from a nickel smelter slag [25].

The current study was undertaken to investigate the dissolution behaviour of selected metals, from the $\mathrm{Cu}, \mathrm{Ni}, \mathrm{Fe}$, and $\mathrm{Zn}$ rich intermediate of base metal production. The focus was to dissolve copper selectively in order to produce PLS rich in copper and a residue with Fe and Ni, applicable for recovery of metals. The lixiviants used in the present study were $0.5-0.5 \mathrm{M} \mathrm{HCl}, 0.5-3.06 \mathrm{M} \mathrm{H}_{2} \mathrm{SO}_{4}$, 1-2 $\mathrm{M} \mathrm{HNO}_{3}, 0.5 \mathrm{M} \mathrm{NaCl}+0.1 \mathrm{M} \mathrm{CuCl}_{2}, 4.5 \mathrm{M} \mathrm{NaCl}+0.5 \mathrm{M} \mathrm{CuCl}_{2}, 4.5 \mathrm{M} \mathrm{NaCl}+0.1 \mathrm{M} \mathrm{CuCl}_{2}$, and 4 $\mathrm{M} \mathrm{NaOH}$.

\section{Materials and Methods}

Characterization studies by Scanning Electron Microscopy (SEM), X-ray diffraction (XRD), and Particle Size Distribution (PSD) were conducted to determine the morphology, mineralogical composition, and elemental distribution of the raw material.

\subsection{The Raw Material}

Chemical analysis of the raw material was performed by employing microwave-assisted digestion in aqua regia (ETHOS Touch Control, Milestone Microwave Laboratory Systems, Sorisole, Italy), as aqua regia is one of the strongest and effective solvent used for metal digestion [26], Table 1. The solution analyses were conducted by ICP-OES (Inductively Coupled Plasma Optical Emission Spectroscopy, Perkin Elmer Optima 7100 DV, Waltham, MA, USA) by Milomatic Oy. 
Table 1. Chemical analysis of metals of interest in raw material investigated.

\begin{tabular}{cc}
\hline Element & Concentration [wt. \%] \\
\hline $\mathrm{Cu}$ & 12.5 \\
$\mathrm{Fe}$ & 23.6 \\
$\mathrm{Ni}$ & 2.6 \\
$\mathrm{Al}$ & 0.5 \\
$\mathrm{Cr}$ & 0.1 \\
$\mathrm{Zn}$ & 1.6 \\
$\mathrm{~Pb}$ & 0.1 \\
$\mathrm{As}$ & 0.1 \\
\hline
\end{tabular}

The particle size of the crushed intermediate raw material was analyzed by a Mastersizer 2000 laser diffraction particle size analyzer with a Scirocco 2000 Dry Powder Feeder, both manufactured by Malvern Instruments (UK). Dispersion pressure was varied from 2.0 to 3.0 bar, vibration feed rate was $50 \%$ and measurement time was varied from 12 to $30 \mathrm{~s}$. Fraunhofer diffraction model was used as an optical model. The particle size distribution of the homogenized raw material is demonstrated in the volume versus particle size diagram, Figure 1 . The size distribution was observed to extend from $1.4 \mu \mathrm{m}$ to $1905 \mu \mathrm{m}$. The cumulative particle size distribution revealed $\mathrm{D}_{80}$ value of $123 \mu \mathrm{m}$. The mean particle size $D_{10}=13 \mu \mathrm{m}$, the surface weighted mean was $D_{32}=25 \mu \mathrm{m}$, and the volume weighted mean $\mathrm{D}_{43}=114 \mu \mathrm{m}$.

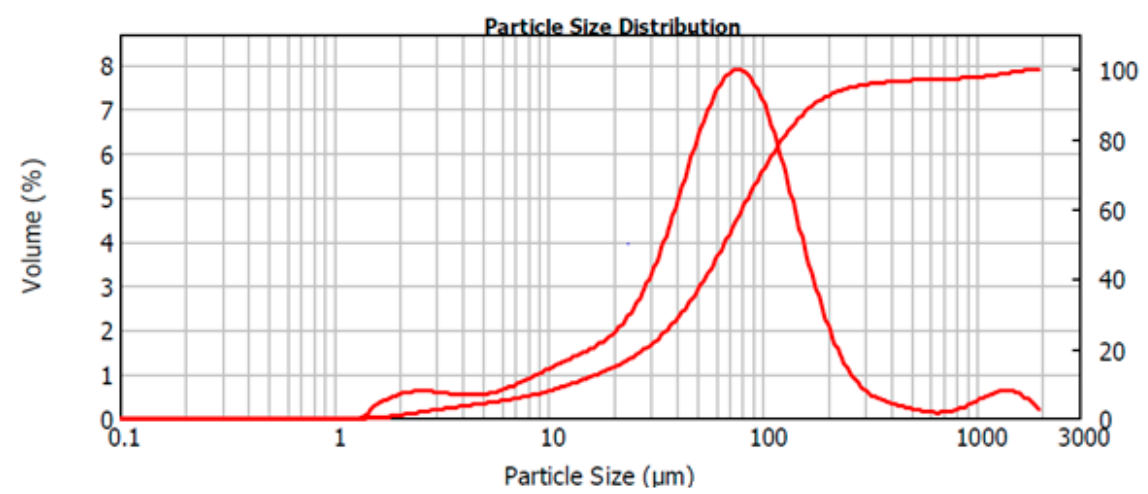

Figure 1. The observed particle size distribution of the homogenized raw material.

An X'Pert PRO-PAN Analytical X-ray diffractometer, operating at an anode current of $40 \mathrm{~mA}$ at $45 \mathrm{kV}$ with a Cuka, by Rietveld refinement method [27] using HighScore Plus software (PANalytical), performed mineralogical analysis of the sample. Fixed Divergence Slit (FDS) $1 / 2^{\circ}$ was fitted in the incident beam path to control the equatorial divergence of the incident beam and fixed incident beam. A copper mask of $15 \mathrm{~mm}$ was fitted in the incident beam path to control the axial width of the incident beam. Fixed Anti-Scatter Slit (FASS) $1^{\circ}$ was used to reduce background signal. The XRD analysis of the raw material by Rietveld refinement suggested a composition of $52.2 \mathrm{wt}$. $\% \mathrm{NiFe}_{2} \mathrm{O}_{4}, 25.0 \mathrm{wt}$. \% $\mathrm{Fe}_{2} \mathrm{SiO}_{4}$ (fayalite), 20.5 wt. \% of $\mathrm{Cu}_{2} \mathrm{O}$ (cuprite), and $2.3 \mathrm{wt}$ \% of metallic $\mathrm{Cu}$, Figure 2 .

SEM-EDS analysis for two raw material samples was performed with a LEO 1450 VP (Carl Zeiss, Oberkochen, Germany) scanning electron microscope (SEM) and a X-MAX-50 $\mathrm{mm}^{2}$ energy dispersive X-ray spectrometer (EDS) with INCA Software (Oxford Instruments, Abingdon, UK). Tungsten filament was used as a cathode and the acceleration voltage used was $15 \mathrm{kV}$.

The raw material samples were cast in epoxy and treated in vacuum, for eliminating gas bubbles attached into the particles, and prepared for SEM-EDS examination polished sections using standard wet methods. It can be discerned from Figure 3 that a larger particle of size around $500 \mu \mathrm{m}$ is encompassed by smaller particles of particle size ranging $2-50 \mu \mathrm{m}$ in the raw material. Three phases could be observed, one of the larger particles and two phases in the smaller particles. The average 
weight percentages of the elements detected in spectrum 1-14 in Figure 3 are presented in Table 2. The lightest color in the back scattered electron (BSE) image corresponds to the phase of the larger particle. It consisted of an average of $88.6 \mathrm{wt}$. \% Cu, $1.9 \mathrm{wt}$. \% Fe, $8.8 \mathrm{wt}$. \% O, and $0.6 \mathrm{wt}$. \% Si (Spectra 1-5), suggesting the presence of $\mathrm{Cu}$ and $\mathrm{Cu}_{2} \mathrm{O}$ (cuprite), as analyzed oxygen eventually is trace from a surface contamination. The light-gray areas in spectra 6, 9, and 12 correspond to an average of 2.2 wt. \% Cu, 52.4 wt. \% Fe, 14.7 wt. \% Ni, 23.8 wt. \% O, and 0.6 wt. \% Si (Spectra 6-9, 14), indicating the three main phases, namely $\mathrm{Fe}_{2} \mathrm{SiO}_{4}$, possibly $\mathrm{NiFe}_{2} \mathrm{O}_{4}$ and $\mathrm{Cu}_{2} \mathrm{O}$. Nevertheless, the dark-gray region represented by Spectra 10-12, consisted of an average of $3.2 \mathrm{wt}$. \% Cu, $3.2 \mathrm{wt}$. \% Fe, $1.1 \mathrm{wt}$ \% $\mathrm{Ni}, 45.8$ wt. \% O, and 32.3 wt. \% Si, corresponding to the presence of almost pure $\mathrm{SiO}_{2}$. Spectra 13 corresponds to epoxy, where samples were casted.

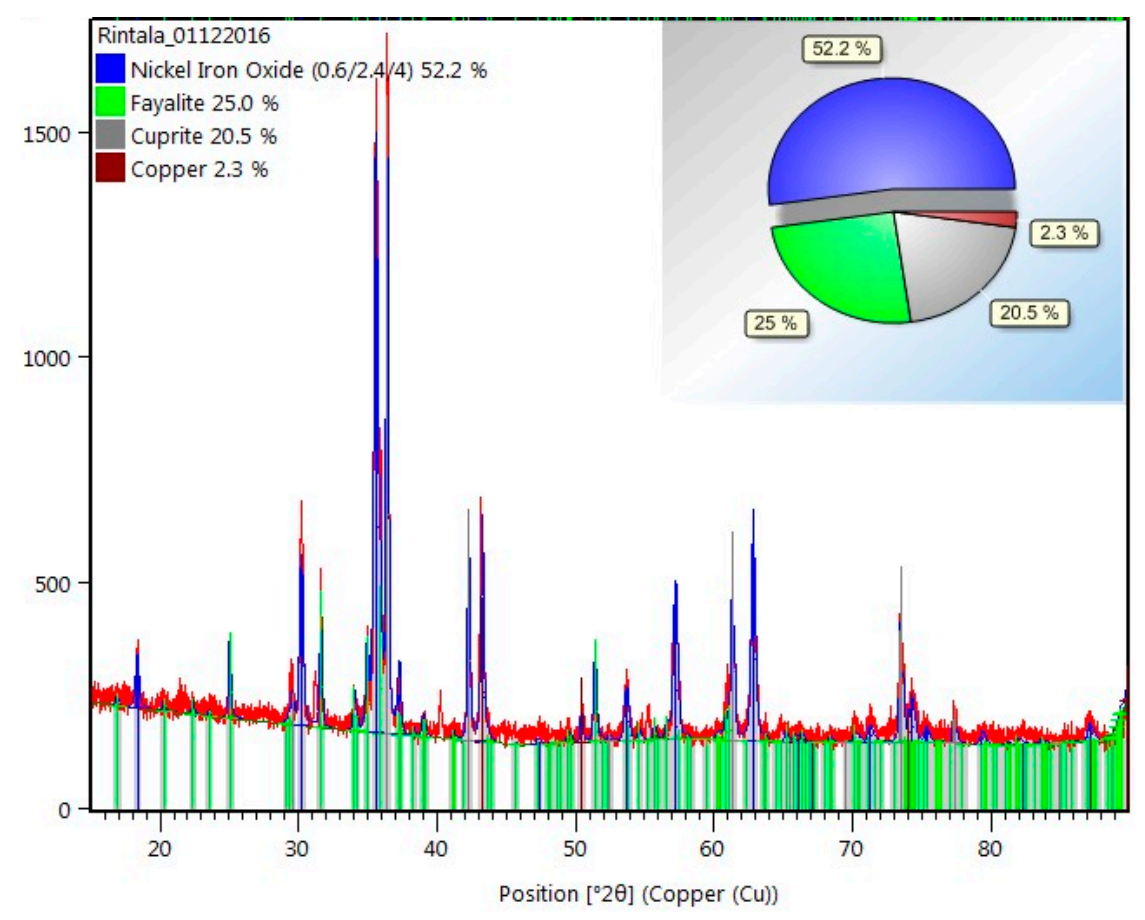

Figure 2. The obtained X-ray diffraction (XRD) pattern of the raw material.

Table 2. SEM-EDS point analysis of the particles presented in Figure 3.

\begin{tabular}{cccc}
\hline [wt. \%] & Spectra \#1-5 & Spectra \#6-9, 14 & Spectra \#10-12 \\
\hline $\mathrm{Cu}$ & 88.6 & 2.2 & 3.2 \\
$\mathrm{Fe}$ & 1.9 & 52.4 & 3.2 \\
$\mathrm{Ni}$ & - & 14.7 & 1.1 \\
$\mathrm{O}$ & 8.8 & 23.8 & 45.8 \\
$\mathrm{Si}$ & 0.6 & 0.6 & 32.3 \\
$\mathrm{Na}$ & - & - & 0.9 \\
$\mathrm{Mg}$ & - & 1.0 & 3.7 \\
$\mathrm{Al}$ & - & 1.7 & 3.6 \\
$\mathrm{~K}$ & - & - & 1.9 \\
$\mathrm{Ca}$ & - & - & 0.7 \\
$\mathrm{Ti}$ & - & 0.8 & 0.4 \\
$\mathrm{Cr}$ & - & 1.9 & - \\
$\mathrm{Zn}$ & - & 2.0 & - \\
$\mathrm{Pb}$ & - & - & 4.3 \\
\hline
\end{tabular}




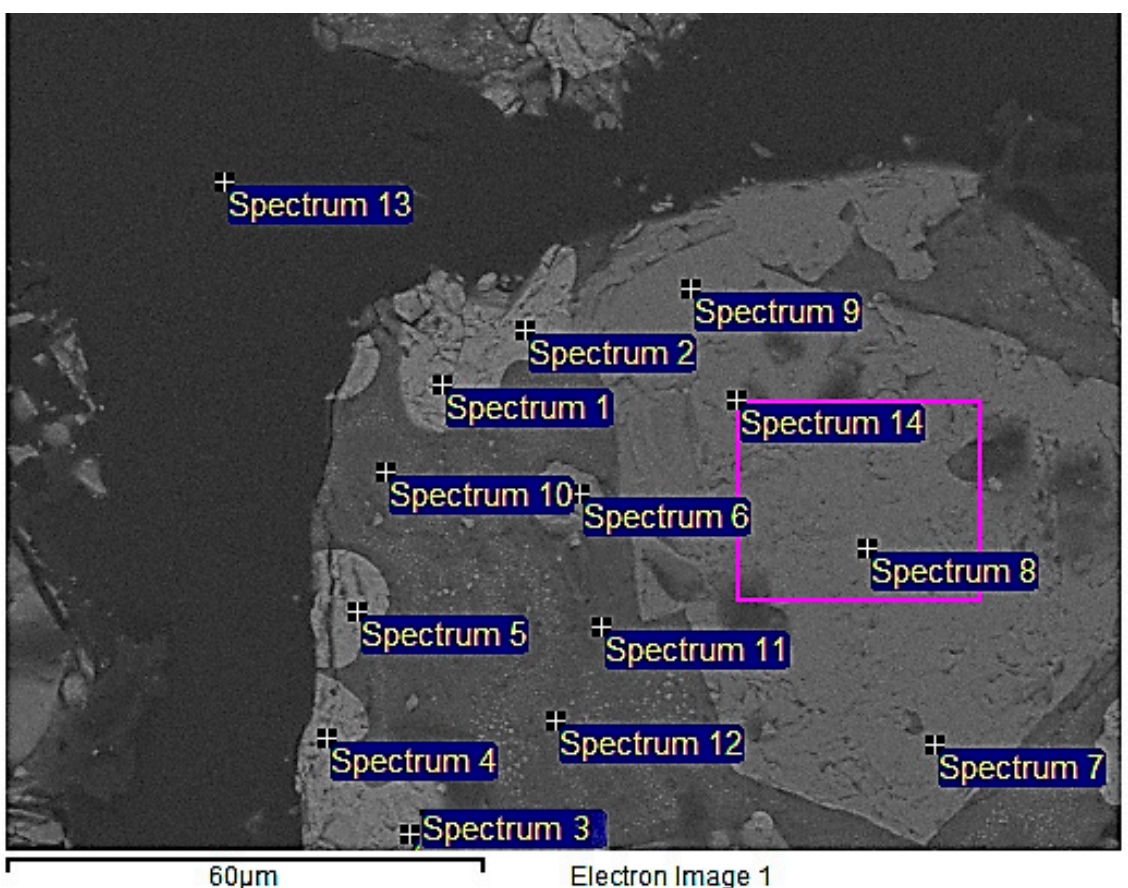

Figure 3. Back scattered Scanning Electron Microscopy (SEM) micrograph of the overall raw material. Spectra 1-5 ( $\mathrm{Cu}_{2} \mathrm{O}$ phase), Spectra $6-9,14\left(\mathrm{NiFe}_{2} \mathrm{O}_{4}\right.$ phase $)$.

\subsection{Leaching Experiments}

In order to investigate the extraction without external heating, leaching was conducted at ambient temperature $\left(25^{\circ} \mathrm{C}\right)$ for $48 \mathrm{~h}$ in several solutions (Table 3$)$. Leaching experiments were conducted in an Erlenmeyer flasks and the solutions were mixed by an IKA RO 10 Multi Station Digital Magnetic Stirrer at $300 \mathrm{RPM}$. The used S/L ratio was 0.025 (5 g solids $/ 200 \mathrm{~mL}$ solution). To evaluate the leaching efficiency of $\mathrm{Ni}, \mathrm{Zn}, \mathrm{Cr}, \mathrm{Pb}, \mathrm{Cu}, \mathrm{Fe}$, and $\mathrm{Al}$, the solution was filtered after the leaching step and the filtrate was analysed by AAS (atomic absorption spectrophotometer), using a Varian AA240 (Varian, Palo Alto, CA, USA), and ICP-OES [28,29].

Table 3. Solutions used in the leaching tests.

\begin{tabular}{|c|c|c|c|}
\hline Solution & Concentrations & Chemicals & Manufacturer (Grade) \\
\hline $\mathrm{HCl}$ & $\begin{array}{c}0.5 \mathrm{M} \\
1.5 \mathrm{M} \\
2.5 \mathrm{M} \\
3.0 \mathrm{M} \\
5 \mathrm{M}\end{array}$ & $\mathrm{HCl} 37 \%$ & EMPARTA ACS (for analysis) \\
\hline $\mathrm{H}_{2} \mathrm{SO}_{4}$ & $\begin{array}{l}0.51 \mathrm{M} \\
1.22 \mathrm{M} \\
1.93 \mathrm{M} \\
2.65 \mathrm{M} \\
3.06 \mathrm{M}\end{array}$ & $\mathrm{H}_{2} \mathrm{SO}_{4} 95-97 \%$ & EMSURE ISO (for analysis) \\
\hline $\mathrm{HNO}_{3}$ & $1 \mathrm{M}$ & $\mathrm{HNO}_{3} 65 \%$ & EMSURE (for analysis) \\
\hline $\mathrm{CuCl}_{2}, \mathrm{pH} 1$ & $\begin{array}{l}0.5 \mathrm{M} \mathrm{NaCl}+0.1 \mathrm{M} \mathrm{CuCl}_{2} \\
4.5 \mathrm{M} \mathrm{NaCl}+0.5 \mathrm{M} \mathrm{CuCl}_{2} \\
4.5 \mathrm{M} \mathrm{NaCl}+0.1 \mathrm{M} \mathrm{CuCl}_{2}\end{array}$ & $\mathrm{CuCl}_{2} \cdot 2 \mathrm{H}_{2} \mathrm{O}$ & VWR Chemicals (technical) \\
\hline $\mathrm{NaOH}$ & $4 \mathrm{M}$ & $\mathrm{NaOH}$ & SIGMA-ALDRICH (technical) \\
\hline
\end{tabular}

No external oxidation by gas bubbling was used in the experiments. Redox potential was measured by a Fluke 115 True RMS Multimeter using platinum wire and Saturated Calomel Electrode (SCE). Mettler Toledo Seven (Easy pH meter) was used for $\mathrm{pH}$ measurements, except in the $\mathrm{NaOH}$ solutions, where Hanna Instruments Edge $\mathrm{pH}$ meter was employed. 


\section{Results and Discussion}

Leaching was performed on the raw material to get an insight into the dissolution phenomena related to $\mathrm{Cu}, \mathrm{Ni}, \mathrm{Zn}$, and $\mathrm{Fe}$ in various lixiviants. Also leaching of trace metals, such as $\mathrm{Cr}, \mathrm{Pb}$, and $\mathrm{Al}$, was explored. The aim was to find a selective, low temperature, and low chemical consumption leaching procedure for copper present in the raw material. Furthermore, the target was to leave nickel in the leach residue in the leaching stage.

Table 4 presents the metal yields to the solution in all 16 investigated media. The corresponding redox potentials, as well as pHs before and after the experiment are presented in Figure 4 . It can be seen that there is some variety in the recovery percentage - this is most likely attributed to the heterogeneous nature of the investigated raw material with big particle size and wide particle size range combined with small solid/liquid ratio in the leaching experiments. This leads in to some variation in the representativeness of each sample, thus also resulting some error in the recovery calculations.

Table 4. Extraction of investigated metals from the raw material (\%).

\begin{tabular}{cccccccc}
\hline Solution & $\mathbf{N i}$ & $\mathbf{C u}$ & $\mathbf{F e}$ & $\mathbf{Z n}$ & $\mathbf{C r}$ & $\mathbf{P b}$ & $\mathbf{A l}$ \\
\hline $0.5 \mathrm{M} \mathrm{HCl}$ & 10 & $*$ & 55 & 40 & 20 & 98 & 39 \\
$1.5 \mathrm{M} \mathrm{HCl}$ & 18 & $*$ & 78 & 48 & 45 & 93 & 56 \\
$2.5 \mathrm{M} \mathrm{HCl}$ & 43 & 95 & 81 & 64 & 67 & 97 & 69 \\
$3 \mathrm{M} \mathrm{HCl}$ & 97 & 72 & 54 & 66 & 84 & 99 & 71 \\
$5 \mathrm{M} \mathrm{HCl}$ & 96 & 86 & 74 & 92 & 55 & 97 & 79 \\
$0.5 \mathrm{M} \mathrm{H}_{2} \mathrm{SO}_{4}$ & 35 & 70 & 53 & 63 & 84 & 21 & 51 \\
$1.22 \mathrm{M} \mathrm{H}_{2} \mathrm{SO}_{4}$ & 64 & 77 & 60 & 76 & 56 & 23 & 63 \\
$1.93 \mathrm{M} \mathrm{H}_{2} \mathrm{SO}_{4}$ & 77 & 81 & 82 & 80 & 62 & 23 & 69 \\
$2.65 \mathrm{M} \mathrm{H}_{2} \mathrm{SO}_{4}$ & 86 & 71 & 78 & 86 & 57 & 23 & 65 \\
$3.0 \mathrm{M} \mathrm{H}_{2} \mathrm{SO}_{4}$ & 81 & 65 & 62 & 86 & 56 & 17 & 65 \\
$4.5 \mathrm{M} \mathrm{NaCl}+\mathrm{M} \mathrm{M} \mathrm{Cu}^{2+} \mathrm{pH} 1$ & 1 & 5 & - & 1 & - & 65 & 7 \\
$4.5 \mathrm{M} \mathrm{NaCl}+\mathrm{M} \mathrm{M} \mathrm{Cu}^{2+} \mathrm{pH} 1$ & 1 & 3 & - & 1 & - & 62 & 5 \\
$0.5 \mathrm{M} \mathrm{NaCl}+\mathrm{M} \mathrm{M} \mathrm{Cu}^{2+} \mathrm{pH} 1$ & 3 & 61 & - & 27 & - & 53 & 5 \\
$1 \mathrm{M} \mathrm{HNO}_{3}$ & 3 & 79 & - & 30 & - & 98 & 16 \\
$2 \mathrm{M} \mathrm{HNO}_{3}$ & 4 & 93 & - & 30 & - & $*$ & 13 \\
$4 \mathrm{M} \mathrm{NaOH}^{\mathrm{NaOH}}$ & 0.3 & $*$ & - & 2 & - & 59 & 22 \\
\hline
\end{tabular}

${ }^{*}$ Full leaching.

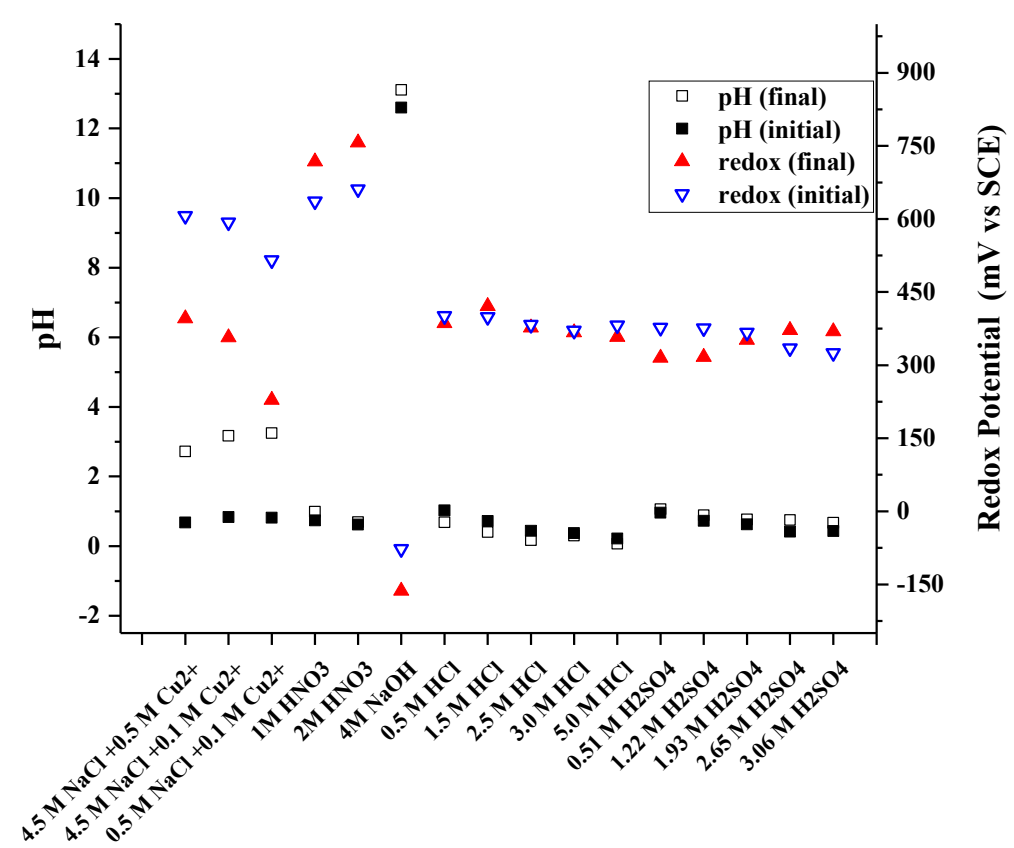

Figure 4. Measured redox potentials and $\mathrm{pH}$ during leaching in 16 investigated leaching media. 


\subsection{Leaching of Copper}

Table 4 shows that copper was dissolved well into most lixiviants investigated. The highest extraction of $\mathrm{Cu}$ was achieved with $1.5 \mathrm{M} \mathrm{HCl}$. Also $4 \mathrm{M} \mathrm{NaOH}, 0.5 \mathrm{M} \mathrm{HCl}, 2.5 \mathrm{M} \mathrm{HCl}$, and $2 \mathrm{M} \mathrm{HNO}_{3}$ resulted in yields higher than $93 \%$, and $1 \mathrm{M} \mathrm{HNO}_{3}, 1.22 \mathrm{M} \mathrm{H}_{2} \mathrm{SO}_{4}$, and $1.93 \mathrm{M} \mathrm{H}_{2} \mathrm{SO}_{4}$ showed $>75 \%$ extraction. The chloride leaching experiments ( 0.1 and $0.5 \mathrm{M}$ of copper (II) as oxidant along with $4.5 \mathrm{M} \mathrm{NaCl}$ ) showed only minor $\mathrm{Cu}$ dissolution $(\leq 5 \%)$, most likely due to a final $\mathrm{pH}$ close to 3 (see Figure 4), indicating copper precipitation as atacamite [30]. Sulfuric acid concentration increase was shown to increase $\mathrm{Cu}$ extraction up to $80 \%$ at $1.93 \mathrm{M}$, however at higher concentrations the extraction was decreased, being $65 \%$ at $3.0 \mathrm{M} \mathrm{H}_{2} \mathrm{SO}_{4}$. The extraction efficiency of copper was found to be comparatively lower in $\mathrm{H}_{2} \mathrm{SO}_{4}$ than in $\mathrm{HCl}$ and $\mathrm{HNO}_{3}$ medium (Table 4). Habashi et al. [31] have suggested that since $\mathrm{HCl}$ and $\mathrm{HNO}_{3}$ generate 1 mole of $\mathrm{H}^{+}$ions when dissolved in water, they produce similar dissolution efficiency compared to $\mathrm{H}_{2} \mathrm{SO}_{4}$, which produces 2 moles of $\mathrm{H}^{+}$ions. Also, the extraction efficiency of $\mathrm{Cu}$ was higher in $2 \mathrm{M} \mathrm{HNO}_{3}$ than in $1 \mathrm{M} \mathrm{HNO}_{3}$ (Table 4) as the oxidizing potential of $\mathrm{NO}_{3}{ }^{-}$ions has been reported to increase with increase in solution acidity [32].

In chloride media, it is suggested that cuprous chloride complexes $\mathrm{CuCl}_{3}{ }^{2-}$ and $\mathrm{CuCl}_{4}{ }^{3-}$ will be produced sequentially from $\mathrm{CuCl}_{2}{ }^{-}$with chloride concentration above $1 \mathrm{M}$ [33]. Chloride ions complexes can stabilize $\mathrm{Cu}(\mathrm{I})$ ions thereby increasing copper solubility. The complexation also increases the redox potential of $\mathrm{Cu}(\mathrm{II}) / \mathrm{Cu}(\mathrm{I})$ thereby enhancing the oxidative power of the solution. Copper is also known to be dissolvable at high $\mathrm{pHs}$ such as in $4 \mathrm{M} \mathrm{NaOH}$ media. The $\mathrm{pH}$ values measured in $\mathrm{NaOH}$ leaching (Figure 4) suggest the prevailing species as $\mathrm{Cu}(\mathrm{OH})_{3}{ }^{-}$[34].

The suggested reactions acid/basic leaching reactions in $\mathrm{HCl}(3)$, sulfuric acid (4), and basic $\mathrm{NaOH}(5)$ for $\mathrm{Cu}_{2} \mathrm{O}$, are presented below with their standard Gibbs energies of the reactions at $25^{\circ} \mathrm{C}$ from HSC Chemistry database [35]:

$$
\begin{gathered}
\mathrm{Cu}_{2} \mathrm{O}+8 \mathrm{HCl}_{(\mathrm{a})}=2 \mathrm{CuCl}_{4}{ }^{3-}{ }_{(\mathrm{a})}+6 \mathrm{H}^{+}{ }_{(\mathrm{a})}+\mathrm{H}_{2} \mathrm{O}_{(\mathrm{a})}, \Delta \mathrm{G}^{\circ}=-121.28 \mathrm{kcal} / \mathrm{mol} \\
\mathrm{Cu}_{2} \mathrm{O}+\mathrm{H}_{2} \mathrm{SO}_{4(\mathrm{l})}=\mathrm{Cu}+\mathrm{CuSO}_{4(\mathrm{ia})}+\mathrm{H}_{2} \mathrm{O}_{(\mathrm{a})}, \Delta \mathrm{G}^{\circ}=-14.71 \mathrm{kcal} / \mathrm{mol} \\
\mathrm{Cu}_{2} \mathrm{O}+4 \mathrm{NaOH}_{(\mathrm{a})}+\mathrm{H}_{2} \mathrm{O}_{(\mathrm{a})}=2 \mathrm{Cu}(\mathrm{OH})_{3}{ }^{-}{ }_{(\mathrm{a})}+4 \mathrm{Na}^{+}{ }_{(\mathrm{a})}+2 \mathrm{e}^{-}, \Delta \mathrm{G}^{\circ}=-28.13 \mathrm{kcal} / \mathrm{mol}
\end{gathered}
$$

The species (a), (ia) and (l) refers to aqueous, neutral aqueous and liquid phase.

\subsection{Ni Leaching and Selectivity between Copper and Nickel}

According to the mineralogy, the prevailing nickel phase in the raw material investigated is nickel ferrite $\mathrm{NiFe}_{2} \mathrm{O}_{4}$. Ferrites are known to be refractory in leaching. This is confirmed by the results which showed that the maximum $\mathrm{Ni}$ extraction $(97 \%)$ was observed in aggressive concentrated leaching media (3-5 M HCl). The suggested leaching reactions in $\mathrm{HCl}$ are presented in (6) and (7). From the speciation diagram of nickel containing $\mathrm{NiCl}_{2}$ and $\mathrm{HCl}$ [36], most nickel is suggested to exist as $\mathrm{Ni}^{2+}$ up to $5 \mathrm{M} \mathrm{HCl}$. However, the concentration of $\mathrm{NiCl}^{+}$gradually increases with increases in $\mathrm{HCl}$. Nickel dissolution did not show any selectivity versus iron in any of the leaching media investigated. This is due to the dominating $\mathrm{Ni}$ phase $\mathrm{NiFe}_{2} \mathrm{O}_{4}$ resulting in a simultaneous $\mathrm{Ni}$ and $\mathrm{Fe}$ dissolution. Also, in the absence of neutralization, no back precipitation was observed.

$$
\begin{gathered}
\mathrm{NiFe}_{2} \mathrm{O}_{4}+8 \mathrm{HCl}_{(\mathrm{a})}=\mathrm{Ni}^{+2}{ }_{\text {(a) }}+2 \mathrm{FeCl}^{+2}{ }_{(\mathrm{a})}+4 \mathrm{H}_{2} \mathrm{O}_{(\mathrm{a})}+6 \mathrm{Cl}^{-}{ }_{(\mathrm{a})}, \Delta \mathrm{G}^{\circ}=-127.78 \mathrm{kcal} / \mathrm{mol} \\
\mathrm{NiFe}_{2} \mathrm{O}_{4}+8 \mathrm{HCl}_{(\mathrm{a})}=\mathrm{NiCl}_{(\mathrm{a})}+2 \mathrm{FeCl}_{2}{ }^{+}{ }_{(\mathrm{a})}+4 \mathrm{H}_{2} \mathrm{O}_{(\mathrm{a})}+3 \mathrm{Cl}^{-}{ }_{(\mathrm{a})}, \Delta \mathrm{G}^{\circ}=-161.17 \mathrm{kcal} / \mathrm{mol}
\end{gathered}
$$

The current study aims to selectively dissolve $\mathrm{Cu}$ versus nickel. Figure 5 presents the dissolved $\mathrm{Cu} / \mathrm{Ni}$ ratio in solution with eight of the most selective lixiviants. It can be seen that the highest selectivity was achieved with $4 \mathrm{M} \mathrm{NaOH}(\mathrm{w}(\mathrm{Cu}): \mathrm{w}(\mathrm{Ni})=340$ in solution). Also 1 and $2 \mathrm{M}$ $\mathrm{HNO}_{3}(\mathrm{w}(\mathrm{Cu}) / \mathrm{w}(\mathrm{Ni})=26$ and 23$)$ provided excellent selectivity as well as $0.5 \mathrm{M} \mathrm{HCl}$ solution $(\mathrm{w}(\mathrm{Cu}) / \mathrm{w}(\mathrm{Ni})=10)$. 


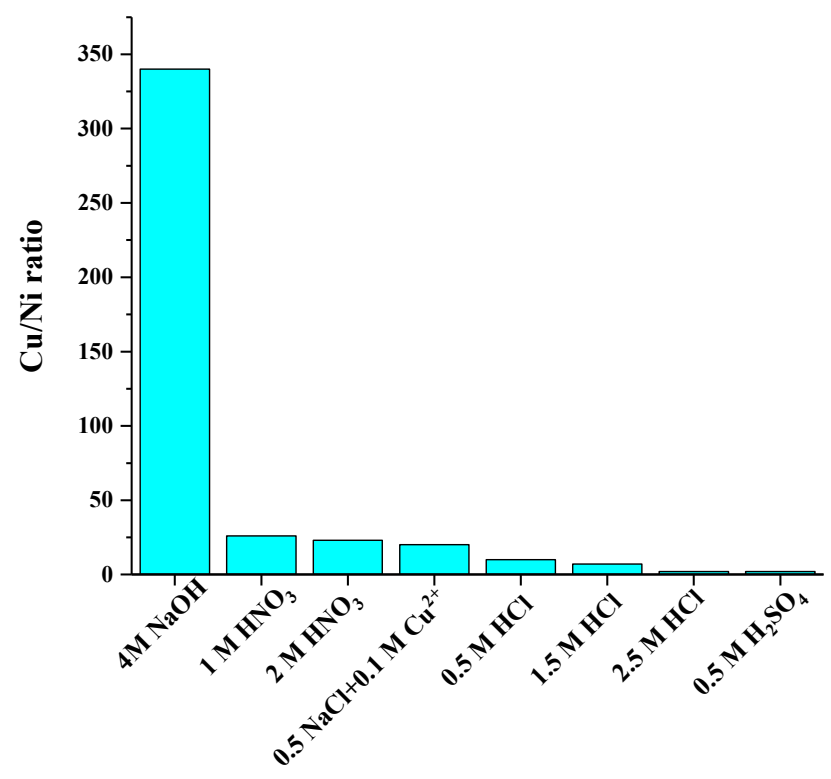

Figure 5. Cu selectivity against $\mathrm{Ni}$ in the best eight selective leaching media.

The lowest $\mathrm{Ni}$ dissolution $(\leq 4 \%)$ was observed with $4 \mathrm{M} \mathrm{NaOH}, 1-2 \mathrm{M} \mathrm{HNO}_{3}$, and all the investigated $\mathrm{NaCl}$ solutions. Dilute $\mathrm{HCl}(0.5 \mathrm{M})$ dissolved only $10 \%$ of nickel.

\subsection{Leaching of Iron}

Iron originated from the two main minerals of the raw material, $\mathrm{NiFe}_{2} \mathrm{O}_{4}$ and $\mathrm{Fe}_{2} \mathrm{SiO}_{4}$. Most notable extractions of $\mathrm{Fe}(81-82 \%)$ was observed in $1.93 \mathrm{M} \mathrm{H}_{2} \mathrm{SO}_{4}$ and $2.5 \mathrm{M} \mathrm{HCl}$. Furthermore, the Fe extraction was high $(>50 \%)$ in all hydrochloric and sulphuric acid media. Generally, no selectivity between iron and nickel or copper was found. However, minor selectivity between $\mathrm{Cu}$ and $\mathrm{Fe}$ was observed in $0.5 \mathrm{M}$ and $1.5 \mathrm{M} \mathrm{HCl}(\mathrm{Cu} / \mathrm{Fe}=1.9$ and 1.5 , respectively).

In chloride media, $\mathrm{Fe}(\mathrm{III})$ forms $\mathrm{FeCl}^{2+}$ and $\mathrm{Fe}^{3+}$ at lower $\mathrm{Cl}^{-}$concentrations, whereas $\mathrm{FeCl}_{2}{ }^{+}$is formed at higher chloride concentration $[37,38]$. The suggested reactions for $\mathrm{NiFe}_{2} \mathrm{O}_{4}$ are presented earlier in (6) and (7), in addition fayalite is suggested to leach according to reactions (8) and (9):

$$
\begin{gathered}
\mathrm{Fe}_{2} \mathrm{SiO}_{4}+2 \mathrm{H}_{2} \mathrm{SO}_{4(\mathrm{l})}=2 \mathrm{FeSO}_{4 \text { (ia) }}+\mathrm{H}_{4} \mathrm{SiO}_{4(\mathrm{a})}, \Delta \mathrm{G}^{\circ}=-51.67 \mathrm{kcal} / \mathrm{mol} \\
\mathrm{H}_{4} \mathrm{SiO}_{4} \text { (colloid) }=\mathrm{SiO}_{2} \cdot 2 \mathrm{H}_{2} \mathrm{O}
\end{gathered}
$$

It is clear that iron dissolution is strongly related to the solution $\mathrm{pH}$. At $\mathrm{pHs}<2$ iron is known to remain soluble [39]. This can be taken as an advantage in the leaching, as $\mathrm{pH}$ adjustment can significantly improve the selectivity between $\mathrm{Cu}$ and Fe.

\subsection{Leaching of Zinc}

The maximum extraction of $\mathrm{Zn}(90 \%)$ was achieved in $5 \mathrm{M} \mathrm{HCl}$. Several researchers [40,41] have reported $90 \%$ recovery of $\mathrm{Zn}$ in leaching of zinc ferrite in the concentration range of $0.5-6 \mathrm{M} \mathrm{HCl}$. When $\mathrm{Zn}$ (II) is dissolved into chloride media, it is known to form complex such as $\mathrm{ZnCl}_{3}{ }^{-}$[42]. Decrease in the $\mathrm{Zn}$ yield from $86 \%$ to $40 \%$ was noticed in the following order of the lixiviants:

$$
\begin{aligned}
2.65 \mathrm{M} \mathrm{H}_{2} \mathrm{SO}_{4}>3.0 \mathrm{M} \mathrm{H}_{2} \mathrm{SO}_{4} & >1.93 \mathrm{M} \mathrm{H}_{2} \mathrm{SO}_{4}>1.23 \mathrm{M} \mathrm{H}_{2} \mathrm{SO}_{4}>3 \mathrm{M} \mathrm{HCl}>2.5 \mathrm{M} \mathrm{HCl} \\
& >0.5 \mathrm{M} \mathrm{H}_{2} \mathrm{SO}_{4}>0.5 \mathrm{M} \mathrm{HCl}
\end{aligned}
$$

However, $\mathrm{Zn}$ extraction was $\leq 30 \%$ in $1-2 \mathrm{M} \mathrm{HNO}_{3}$ and $0.5 \mathrm{M} \mathrm{NaCl}+0.1 \mathrm{M} \mathrm{Cu}^{2+}$. The alkaline leaching of zinc ferrite $(4 \mathrm{M} \mathrm{NaOH})$ was shown to result in lower $\mathrm{Zn}$ extraction compared to $\mathrm{HCl}$ and 
$\mathrm{H}_{2} \mathrm{SO}_{4}$. Zn extraction was found to be $2 \%$ in $4 \mathrm{M} \mathrm{NaOH}$. Thus, zinc ferrite fraction of magnetite was not decomposed even in strong alkaline media. The suggested reactions for Zn dissolution in $\mathrm{HCl}$ (10), and sulfuric acid (11) media are:

$$
\begin{gathered}
\mathrm{ZnFe}_{2} \mathrm{O}_{4}+8 \mathrm{HCl}_{(\mathrm{a})}=\mathrm{ZnCl}_{3}{ }^{-}{ }_{\text {(a) }}+2 \mathrm{FeCl}_{2}{ }^{+}{ }_{\text {(a) }}+4 \mathrm{H}_{2} \mathrm{O}_{(\mathrm{l})}+3 \mathrm{Cl}^{-}{ }_{(\mathrm{a})}, \Delta \mathrm{G}^{\circ}=-124.77 \mathrm{kcal} / \mathrm{mol} \\
\mathrm{ZnFe}_{2} \mathrm{O}_{4}+\mathrm{H}_{2} \mathrm{SO}_{4(\mathrm{l})}=\mathrm{ZnSO}_{4}(\mathrm{a})+\mathrm{Fe}_{2} \mathrm{O}_{3}+\mathrm{H}_{2} \mathrm{O}_{(\mathrm{l})}, \Delta \mathrm{G}^{\circ}=-26.98 \mathrm{kcal} / \mathrm{mol}
\end{gathered}
$$

\subsection{Leaching of $\mathrm{Cr}, \mathrm{Pb}$, and $\mathrm{Al}$}

The dissolution of minor elements, such as $\mathrm{Cr}, \mathrm{Pb}$, and $\mathrm{Al}$, was observed in the investigated leaching solutions. Figure 6 displays a complete 3D schematic representation of the elements of $\mathrm{Al}, \mathrm{Pb}$, and $\mathrm{Cr}$ and shows that generally aluminum had a high solubility into sulfuric acid and $\mathrm{HCl}$ media. Lead had high tendency towards $\mathrm{HCl}, \mathrm{NaOH}, \mathrm{HNO}_{3}$, and chloride leaching, but it was dissolved only slightly into sulfuric acid media, evidently due to the low solubility of lead sulfate.

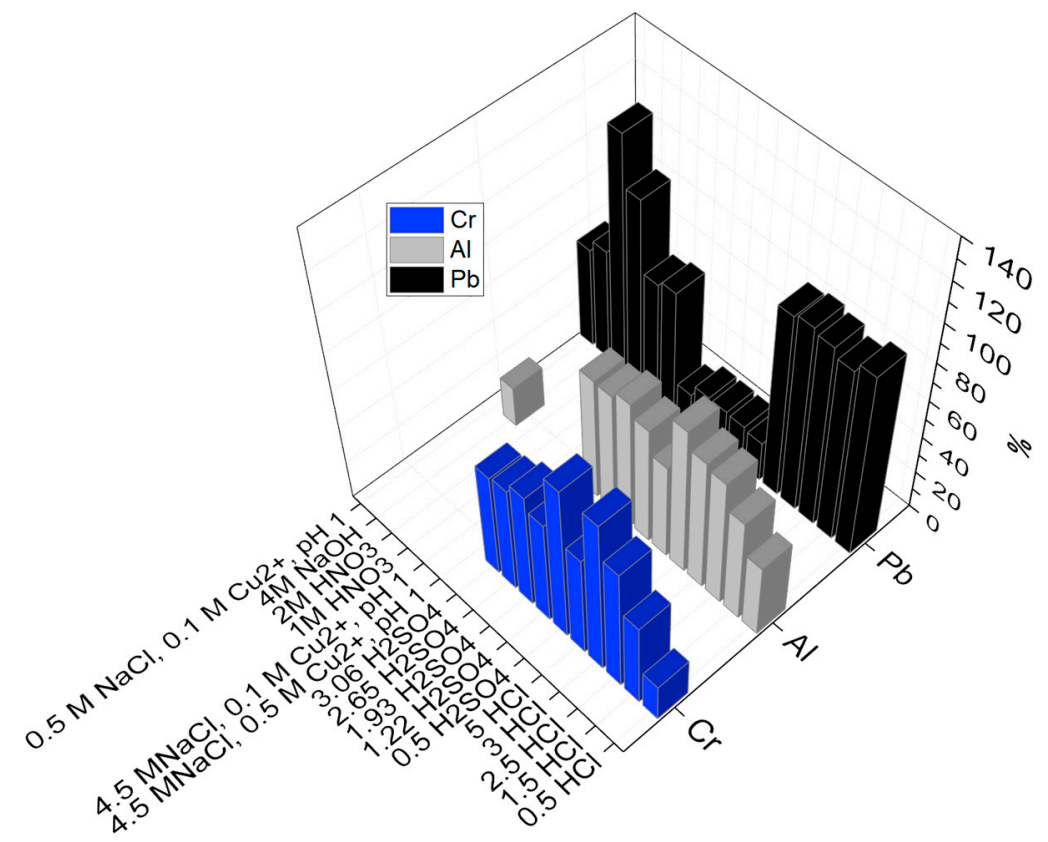

Figure 6. 3D plot displaying the yields of $\mathrm{Al}, \mathrm{Pb}$, and $\mathrm{Cr}$ obtained from the leaching in various lixiviants.

It was also observed from the above graph (Figure 6) that the maximum $\mathrm{Cr}$ yield was $83 \%$ in $3 \mathrm{M} \mathrm{HCl}$. Furthermore, the yield of $\mathrm{Cr}$ decreased from 66 to $20 \%$ in presence of lixiviants in the following order: $2.5 \mathrm{M} \mathrm{HCl}>1.93 \mathrm{M} \mathrm{H}_{2} \mathrm{SO}_{4}>0.5 \mathrm{M} \mathrm{H}_{2} \mathrm{SO}_{4}>2.65 \mathrm{M} \mathrm{H}_{2} \mathrm{SO}_{4}>3.06 \mathrm{M} \mathrm{H}_{2} \mathrm{SO}_{4}>1.22 \mathrm{M}$ $\mathrm{H}_{2} \mathrm{SO}_{4}>5 \mathrm{M} \mathrm{HCl}>1.5 \mathrm{M} \mathrm{HCl}$.

Highest aluminum extraction ( $>70 \%$ ) was observed in 3 and $5 \mathrm{M} \mathrm{HCl}$ solutions. Additionally, all sulphuric acid solutions and $\mathrm{HCl}$ solutions $\geq 1.5 \mathrm{M}$ resulted in higher than $50 \%$ leaching. Yield percentage of $\mathrm{Pb}$ in all the investigated $\mathrm{HCl}$ solutions was high (93-99\%), as $\mathrm{Pb}$ dissolves forming chloride complexes $\mathrm{PbCl}^{+}$and $\mathrm{PbCl}_{2}$ at low $\mathrm{Cl}^{-}$concentrations, and forms $\mathrm{PbCl}^{3-}$ and $\mathrm{PbCl}_{4}{ }^{2-}$ at higher concentrations [43].

\subsection{A Comparison of the Used Lixiviants}

Table 5 shows a comparison of the best copper lixiviants and the selectivities of copper dissolution for nickel and iron. It can be seen that $4 \mathrm{M} \mathrm{NaOH}$ has the highest selectivity in copper extraction. In addition, it has the highest selectivity for $\mathrm{Zn}$ as well. The goal of mild, selective, and low temperature leaching of copper is best approached by the $0.5 \mathrm{M} \mathrm{HCl}$ media, which was able to dissolve all 
copper with only $10 \%$ nickel extraction, selectivity between copper and nickel concentrations in the solution being 10. Furthermore, $0.5 \mathrm{M} \mathrm{HCl}$ was the media showing the highest selectivity towards $\mathrm{Fe}(\mathrm{Cu} / \mathrm{Fe}=1.9)$ without $\mathrm{pH}$ adjustment.

Table 5. The best lixiviants selected for $\mathrm{Cu}, \mathrm{Fe}, \mathrm{Pb}$, and $\mathrm{Zn}$ extraction.

\begin{tabular}{|c|c|c|c|c|c|c|}
\hline Solution & $\begin{array}{c}\text { Cu Extraction } \\
(\%)\end{array}$ & $\begin{array}{c}\mathrm{Cu} / \mathrm{Ni} \\
\text { Selectivity }\end{array}$ & $\begin{array}{c}\mathrm{Cu} / \mathrm{Zn} \\
\text { Selectivity }\end{array}$ & $\begin{array}{c}\mathrm{Cu} / \mathrm{Fe} \\
\text { Selectivity }\end{array}$ & $\begin{array}{c}\text { Pb Extraction } \\
(\%)\end{array}$ & $\begin{array}{c}\text { Zn Extraction } \\
(\%)\end{array}$ \\
\hline $1.5 \mathrm{M} \mathrm{HCl}$ & * & 7 & 3 & 1.5 & 93 & 48 \\
\hline $0.5 \mathrm{M} \mathrm{HCl}$ & * & 10 & 3 & 1.9 & 98 & 40 \\
\hline $4 \mathrm{M} \mathrm{NaOH}$ & * & 340 & 51 & - & 59 & 2 \\
\hline $\begin{array}{l}\text { 0.5 M NaCl, } \\
0.1 \mathrm{M} \mathrm{Cu}^{2+}\end{array}$ & 61 & 20 & 2 & - & 53 & 27 \\
\hline $2 \mathrm{M} \mathrm{HNO}_{3}$ & 93 & 23 & 3 & - & $*$ & 30 \\
\hline $1 \mathrm{M} \mathrm{HNO}_{3}$ & 79 & 26 & 3 & - & 98 & 30 \\
\hline
\end{tabular}

The calculated composition of the residue after $0.5 \mathrm{M} \mathrm{HCl}$ leaching suggests the leach residue composition being $23 \mathrm{mg} / \mathrm{g} \mathrm{Ni}, 106 \mathrm{mg} / \mathrm{g} \mathrm{Fe}, 9 \mathrm{mg} / \mathrm{g} \mathrm{Zn,} 2 \mathrm{mg} / \mathrm{g} \mathrm{Al}, 1.9 \mathrm{mg} / \mathrm{g} \mathrm{Cu}, 0.9 \mathrm{mg} / \mathrm{g} \mathrm{Cr}$, and $0.02 \mathrm{mg} / \mathrm{g} \mathrm{Pb}$. The advantage of $0.5 \mathrm{M} \mathrm{HCl}$ is that it could dissolve also almost all $\mathrm{Pb}(98 \%)$.

\section{Conclusions}

Along the principles of circular economy, the recovery of metals from industrial side streams, waste, and intermediate fractions is of increasing importance. In the current study, the leaching phenomena and selective leaching of copper was investigated from an intermediate raw material originating from base metal production, with a mineralogy of $52.2 \% \mathrm{NiFe}_{2} \mathrm{O}_{4}, 25.0 \% \mathrm{Fe}_{2} \mathrm{SiO}_{4}$ (fayalite), $20.5 \%$ of $\mathrm{Cu}_{2} \mathrm{O}$ (cuprite), and $2.3 \%$ of metallic $\mathrm{Cu}$. In the raw material, the large particles were shown to consist mainly of $\mathrm{Cu}_{2} \mathrm{O}$ and elemental $\mathrm{Cu}$.

Copper present in the raw material was shown to be easily dissolvable, over $98 \% \mathrm{Cu}$ could be dissolved with $0.5 \mathrm{M}, 1.5 \mathrm{M} \mathrm{HCl}$, and $4 \mathrm{M} \mathrm{NaOH}$. In addition, $0.5 \mathrm{M} \mathrm{HCl}$ was shown to provide selectivity towards $\mathrm{Ni}$, with the $\mathrm{Cu} / \mathrm{Ni}$ concentration ratio in solution being 10 . Alkaline leaching in $4 \mathrm{M} \mathrm{NaOH}$ resulted in the highest selectivity for copper leaching, with the ratio of dissolved elements of $\mathrm{Cu} / \mathrm{Ni}=340$ and $\mathrm{Cu} / \mathrm{Zn}=51$. Also 1 and $2 \mathrm{M} \mathrm{HNO}_{3}$ provided high selectivity for copper dissolution with a $\mathrm{Cu} / \mathrm{Ni}$ ratio of 26 and 23, respectively. Aluminum showed high dissolution into sulfuric acid and hydrochloric acid media, the highest $\mathrm{Al}$ extraction being 79\% in $5 \mathrm{M} \mathrm{HCl}$ whereas lead dissolution was strong in $\mathrm{HCl}$, chloride, $\mathrm{NaOH}$, and $\mathrm{HNO}_{3}$. The highest extraction for $\mathrm{Ni}$ was obtained in $5 \mathrm{M} \mathrm{HCl}$.

The results indicate that from the 16 investigated leaching media, hydrochloric acid leaching $(0.5 \mathrm{M} \mathrm{HCl})$ presents the lowest concentration solution matrix for selective and high copper extraction, even at room temperature.

Acknowledgments: This study is a part of NewEco project of EIT Knowledge and Innovation Community Raw Materials consortium. The authors express their deep gratitude to Petri Latostenmaa from Boliden Harjavalta for providing the raw material. The authors also acknowledge Hannu Revitzer for performing the ICP and chemical analyses and Janne Vuori for performing the particle size analyses. Also METSEK project funded by Association of Finnish Steel and Metal Producers, and Raw MATERS Finland Infrastructure supported by Academy of Finland is greatly acknowledged.

Author Contributions: Mari Lundström and Pekka Taskinen conceived and designed the experiments; Lotta Rintala performed the experiments; Petteri Halli analyzed the data; Udit Surya Mohanty and Mari Lundström wrote the paper.

Conflicts of Interest: The authors declare no conflict of interest.

\section{References}

1. Avarmaa, K.; $\mathrm{O}^{\prime}$ Brien, H.; Johto, H.; Taskinen, P. Equilibrium distribution of precious metals between slag and copper matte at $1250-1350{ }^{\circ}$ C. J. Sustain. Metall. 2015, 1, 216-228. [CrossRef] 
2. Avarmaa, K.; Johto, H.; Taskinen, P. Distribution of precious metals (Ag, Au, Pd, Pt, and Rh) between copper matte and iron silicate slag. Metall. Mater. Trans. B 2016, 47, 244-255. [CrossRef]

3. Avarmaa, K.; O’Brien, H.; Taskinen, P. Equilibria of Gold and Silver between Molten Copper and $\mathrm{FeO}_{x}-\mathrm{SiO}_{2}-\mathrm{Al}_{2} \mathrm{O}_{3}$ Slag in WEEE Smelting at $1300{ }^{\circ} \mathrm{C}$. In Advances in Molten Slags, Fluxes, and Salts: Proceedings of the 10th International Conference on Molten Slags, Fluxes and Salts; John Wiley \& Sons, Inc.: Hoboken, NJ, USA, 2016; pp. 193-202.

4. Jyrkonen, S.; Haavanlammi, K.; Luomala, M.; Karonen, J.; Suikkanen, P. Processing of PGM containing $\mathrm{Ni} / \mathrm{Cu}$ bulk concentrates in a sustainable way by Outotec Direct Nickel Flash Smelting process. In $\mathrm{Ni}$-Co 2013; Springer: Cham, Switzerland, 2013; pp. 325-334.

5. Taskinen, P. Direct-to-blister smelting of copper concentrates: The slag fluxing chemistry. Miner. Process. Extr. Metall. 2011, 120, 240-246. [CrossRef]

6. Taskinen, P.; Seppala, K.; Laulumaa, J.; Poijarvi, J. Oxygen pressure in the Outokumpu flash smelting furnace-Part 1: Copper flash smelting settler. Miner. Process. Extr. Metall. 2001, 110, 94-100. [CrossRef]

7. Davenport, W.G.; King, M.J.; Schlesinger, M.E.; Biswas, A.K. Extractive Metallurgy of Copper, 4th ed.; Elsevier: Amsterdam, The Netherlands, 2002; p. 452.

8. Taskinen, P.; Dinsdale, A.; Gisby, J. Industrial slag chemistry: A case study of computational thermodynamics. Scand. J. Metall. 2005, 34, 100-107. [CrossRef]

9. Mihailova, I.; Mehandjiev, D. Characterisation of fayalite from complexes. J. Chem. Technol. Metall. 2010, 45, 317-326.

10. Deng, T.; Ling, Y.H. Chemical and mineralogical characterisations of a copper converter slag. Rare Met. 2002, 21, 175-178.

11. Petkov, V.; Jones, P.T.; Boydens, E.; Blanpain, B.; Wollants, P. Chemical corrosion mechanisms of magnesia-chromite and chrome-free refractory bricks by copper metal and anode slag. J. Eur. Ceram. Soc. 2007, 27, 2433-2444. [CrossRef]

12. Taskinen, P.; Kojo, I. Fluxing options in the direct-to-blister copper smelting. In Proceedings of the Molten 2009 Conference, Santiago, Chile, 18-21 January 2009; pp. 1140-1151.

13. Li, Y.; Papangelakis, G.V.; Ilya, P. High pressure oxidative acid leaching of nickel smelter slag: Characterization of feed and residue. Hydrometallurgy 2009, 97, 185-193. [CrossRef]

14. Altundogan, H.S.; Tumen, F. Metal recovery from copper converter slag by roasting with ferric sulphate. Hydrometallurgy 1997, 44, 261-267. [CrossRef]

15. Sanchez, M.; Parada, F.; Parra, R.; Marquez, F.; Jara, R.; Carrasco, J.; Palcios, J. Management of copper pyrometallurgical slags: Giving additional value to copper mining industry. In Proceedings of the VII International Conference on Molten Slags Fluxes and Salts, Cape Town, South Africa, 25-28 January 2004; pp. 543-550.

16. Geveci, A.; Topkaya, Y.; Gerceker, E. Recovery of Copper and zinc from copper converter flue dusts. In Proceedings of the 10th International Metallurgy and Material Congress, Istanbul, Turkey, 24-28 May 2000; pp. 59-68.

17. Yıldız, K.; Alp, A.; Aydın, A.O. Utilization of copper refining slags by a pyro-hydrometallurgical method. In Proceedings of the 10th International Metallurgy and Material Congress, Istanbul, Turkey, 24-28 May 2000; pp. 127-132.

18. Arslan, F.; Giray, K.; Onal, G.; Gurkan, V. Development of a Flowsheet for Recovering Copper and Tin from Copper Refining Slags. Eur. J. Miner. Process. Environ. Prot. 2002, 2, 94-102.

19. Anand, S.; Das, R.P.; Jena, P.K. Reduction-Roasting and ferric chloride leaching of copper converter slag for extracting copper, nickel and cobalt. Hydrometallurgy 1981, 7, 243-252. [CrossRef]

20. Sukla, L.B.; Panda, S.C.; Jean, P.K. Recovery of cobalt, nickel, and copper from converter slag through roasting with ammonium sulphate and sulfuric acid. Hydrometallurgy 1986, 16, 153-165. [CrossRef]

21. Tumen, F.; Bailey, N.T. Recovery of metal values from copper smelter slags by roasting with pyrite. Hydrometallurgy 1990, 25, 317-328. [CrossRef]

22. Herreros, O.; Quiroza, R.; Manzanob, E.; Bou, C.; Vinalsb, J. Copper extraction from reverberatory and flash furnace slags by chlorine leaching. Hydrometallurgy 1998, 49, 87-101. [CrossRef]

23. Tumen, F. Metal recovery from secondary copper slag by roasting with ammonium sulphate. Turkish J. Eng. Environ. Sci. 1994, 18, 1-5. 
24. Anand, S.; Rao, K.S.; Jena, P.K. Pressure leaching of copper converter slag using dilute sulphuric acid for the extraction of cobalt, nickel and copper values. Hydrometallurgy 1983, 10, 305-312. [CrossRef]

25. Gbor, P.K.; Ahmed, I.B.; Jia, C.Q. Behaviour of Co and Ni during aqueous sulphur dioxide leaching of nickel slag. Hydrometallurgy 2000, 57, 13-22. [CrossRef]

26. Niemela, A.; Pitkaaho, S.; Ojala, S.; Keiski, R.L.; Peramaki, P. Microwave-assisted aqua regia digestion for determining platinum, palladium, rhodium and lead in catalyst materials. Microchem. J. 2012, 101, 75-79. [CrossRef]

27. Young, R.A. The Rietveld Method; Oxford University Press: Oxford, UK, 1995; 308p, ISBN 9780198559122.

28. Cardellicchio, N.; Buccolieri, A.; Di Leo, A.; Spada, L. Heavy metals in marine sediments from the MarPiccolo of Taranto (Ionian Sea, Southern Italy). Ann. Chim. 2006, 96, 727-741. [CrossRef] [PubMed]

29. Cardellicchio, N.; Buccolieri, A.; Di Leo, A.; Librando, V.; Minniti, Z.; Spada, L. Methodological approach for metal pollution evaluation in sediments collected from the Tarnto Gulf. Toxicol. Environ. Chem. 2009, 91, 1273-1290. [CrossRef]

30. Lundstrom, M.; Liipo, J.; Karonen, J.; Aromaa, J. Dissolution of six sulfide concentrates in the hydrocopper environment. In Proceedings of the South African Institute of Mining and Metallurgy Base Metals Conference, Kasane, Botswana, 27-31 July 2009; pp. 127-138.

31. Habbache, N.; Alane, N.; Djerad, S.; Tifouti, L. Leaching of copper oxide with different acid solutions. Chem. Eng. J. 2009, 152, 503-508.

32. Pacović, N.V. Hydrometallurgy; ŠRIF: Bor, Serbia, 1980. Chapter 3. (In Serbian)

33. Carneiro, M.F.C.; Leao, V.A. The role of sodium chloride on surface properties of chalcopyrite leached with ferric sulphate. Hydrometallurgy 2007, 87, 73-82. [CrossRef]

34. Garrels, R.M.; Thompson, M.E. Oxidation of pyrite by iron sulfate solutions. Am. J. Sci. 1960, 258, 57-67.

35. Roine, A. Sustainable Process Technology and Engineering, A Manual on HSC program, Continuous Research \& Development. Outotec Research Centre: Finland, 8 March 2017.

36. Lee, M.S.; Nam, S.H. Chemical Equilibria of Nickel chloride in $\mathrm{HCl}$ solution at $25^{\circ}$ C. Bull. Korean Chem. Soc. 2009, 30, 2203-2207.

37. Ashurst, K.G. The Thermodynamics of the formation of chlorocomplexes of iron (III), cobalt (II), iron (II), manganese (II) in perchlorate medium. Nat. Inst. Metall. 1976, 1820, 1-43.

38. Peek, E.M.; Van Weert, G. Chloride Metallurgy. In Proceedings of the 32nd Annual Hydrometallurgy Meeting and International Conference of the Practice and Theory of Chloride/Metal Interaction, Montréal, QC, Canada, 19-23 October 2002; pp. 760-780.

39. Misawa, T. The thermodynamic consideration for $\mathrm{Fe}-\mathrm{H}_{2} \mathrm{O}$ system at $25^{\circ} \mathrm{C}$. Corros. Sci. 1973, 13, $659-676$. [CrossRef]

40. Langova, S.; Lesko, J.; Matysek, D. Selective leaching of zinc from zinc ferrite with hydrochloric acid. Hydrometallurgy 2009, 95, 179-182. [CrossRef]

41. Nunez, C.; Vinals, J. Kinetics of leaching of zinc ferrite in aqueous hydrochloric acid solutions. Metall. Mater. Trans. B 1984, 15, 221-228. [CrossRef]

42. Sato, T.; Nakamura, T. The stability constants of the aqueous chloro complexes of divalent zinc, cadmium and mercury determined by solvent extraction with tri-n octyl phosphine oxide. Hydrometallurgy 1980, 6, 3-12. [CrossRef]

43. Winand, R. Chloride hydrometallurgy. Hydrometallurgy 1991, 27, 285-316. [CrossRef]

(c) 2018 by the authors. Licensee MDPI, Basel, Switzerland. This article is an open access article distributed under the terms and conditions of the Creative Commons Attribution (CC BY) license (http://creativecommons.org/licenses/by/4.0/). 